Artigo / Article

\title{
New drugs in the therapy of multiple myeloma
}

\section{Novas drogas na terapia do mieloma múltiplo}

Antonio Palumbo

Patrizia Falco

\begin{abstract}
The advances in the understanding of the pathogenesis of multiple myeloma and the mechanism of drug resistance have led to the development of novel targeted therapies that are able to overcome resistance and show additive or synergistic effects with old chemotherapeutic agents. Thalidomide, its immunomodulatory derivative lenalidomide, and the proteasome inhibitor bortezomib, in combination with oral melphalan in the elderly and with intravenous melphalan in younger patients, are changing the traditional treatment paradigm of multiple myeloma. High-dose melphalan followed by autologous stem cell transplantation in the younger patients and oral melphalan-prednisone-thalidomide in the elderly are the standard of care for newly diagnosed multiple myeloma. In younger patients, combinations incorporating thalidomide or lenalidomide or bortezomib significantly increase the pre-transplant response rate before high-dose melphalan and autologous transplantation, and may further improve the response rate and survival achieved after transplant. Prospective randomized studies incorporating new agents and stratifying patients based on cytogenetic abnormalities, are needed to define the therapeutic algorithm in high-risk disease. Rev. bras. hematol. hemoter. 2008;30(Supl. 2):10-17.
\end{abstract}

Key words: Myeloma; lenalidomide; thalidomide; bortezomib; therapy.

\section{Introduction}

Multiple myeloma (MM) is a malignant plasma cell disorders that accounts for approximately $10 \%$ of hematologic malignancies. ${ }^{1,2}$ At diagnosis, the majority of patients are older then 65 years; about a third of myeloma patients are younger than 65 years, and a third are older than 75 years of age. ${ }^{3}$

In newly diagnosed myeloma patients younger than 65 years, high-dose melphalan followed by autologous stem cell transplantation is considered the standard of care. In elderly patients, usually older than 65 years, oral melphalan and prednisone (MP) has been considered the standard until recently.

The introduction of new drugs, such as thalidomide, lenalidomide and the proteasome inhibitor bortezomib, targeting both the myeloma cells and the bone marrow microenvironment has significantly increased the clinical efficacy of the old chemotherapy regimens. The target is now to define the optimal sequence and combination of these drugs to significantly impact the natural history of the disease. (Table 1).

\section{Treatment of myeloma in patients eligible for transplantation}

Initial therapy for patients with newly diagnosed multiple myeloma is dependent on eligibility for autologous stem cell transplantation (ASCT), determined by age, performance status, and coexisting comorbidities. Front-line autologous transplant is generally preceded by few courses of conventional chemotherapy that are aimed to reduce tumor cell mass prior to stem-cell mobilization. At present, vincristine, doxorubicin and dexamethasone (VAD) have been widely used as induction therapies, as well as dexamethasone

Divisione di Ematologia dell'Università di Torino, Azienda Ospedaliera S. Giovanni Battista, Ospedale Molinette, Turin, Italy.

Correspondence: Antonio Palumbo

Divisione di Ematologia dell'Università di Torino

Azienda Ospedaliera S. Giovanni Battista, Ospedale Molinette

Via Genova 3

10126 - Torino, Italy

Phone +39-011-6334418 +39-0116336107; Fax +39-011-6963737

E-mail:gismm2001@yahoo.com 
alone, while induction therapy with melphalan-based regimen should be avoided in patients who are considered eligible for ASCT, since it can interfere with adequate stem cell mobilization.

Vincristine, doxorubicin, dexamethasone (VAD) was used for many years as pre-transplant induction therapy. However, VAD has drawbacks such as needing an intravenous indwelling catheter, and neurotoxicity from vincristine which can limit the future use of thalidomide and bortezomib. Recently, Cavo and colleagues in a matched case-control study of 200 patients demonstrated that response rates with VAD were significantly lower compared to thalidomidedexamethasone combination (Thal/Dex), 76\% versus 52\%, respectively. ${ }^{4}$ Preliminary results from randomized trials confirm these findings. ${ }^{5-6}$ As a result, VAD is not recommended anymore as initial therapy and Thal/Dex has increasingly been used in place of VAD. The inclusion of Thalidomide into the high-dose therapy schema followed by autologous transplantation led to a higher CR rate $(62 \%$ vs $43 \%$ ) and improved 5-year event-free survival (56\% vs $44 \%$ ) compared with high-dose therapy without thalidomide. ${ }^{7}$ Unfortunately, the 5-year overall survival (OS) was similar in both groups $(\mathrm{p}=0.9)$. In the thalidomide group, a higher rate of thromboembolism (30\% vs 17\%) and peripheral neuropathy (27\% vs 17\%) were reported.

Dexamethasone alone has also been used as induction therapy, with an objective response rates of approximately $45 \%,{ }^{8}$ significantly lower compared to newer induction regimens. In randomized trials the early mortality rate associated with dexamethasone is over $10 \%$ in the first 4 months of therapy, reflecting the toxicity and ineffectiveness of this regimen. Consequently, single-agent

Table 1. New regimens for the treatment of newly diagnosed multiple myeloma

\begin{tabular}{ll}
\hline \multicolumn{1}{c}{ Regimen } & \\
\hline $\begin{array}{l}\text { Thalidomide-Dexamethasone } \\
\text { (Thal/Dex) }\end{array}$ & $\begin{array}{l}\text { Thalidomide } 200 \mathrm{mg} \text { oral days } 1-28 \\
\text { Dexamethasone } 40 \mathrm{mg} \text { oral days } 1-4 \\
\text { Repeated every } 4 \text { weeks } \times 4 \text { cycles as pre-transplant induction therapy; } \\
\text { or continued till plateau or progression if used as primary therapy }\end{array}$ \\
$\begin{array}{l}\text { Lenalidomide-Dexamethasone } \\
\text { (Rev/low-dose Dex) }\end{array}$ & $\begin{array}{l}\text { Lenalidomide } 25 \mathrm{mg} \text { oral days } 1-21 \text { every } 28 \text { days } \\
\text { Dexamethasone } 40 \mathrm{mg} \text { oral days } 1,8,15,22 \text { every } 28 \text { days }\end{array}$ \\
& $\begin{array}{l}\text { Repeated every } 4 \text { weeks } \times 4 \text { cycles as pre-transplant induction therapy; } \\
\text { or continued till plateau or progression if used as primary therapy }\end{array}$ \\
Bortezomib-Dex & Bortezomib $1.3 \mathrm{mg} / \mathrm{m}^{2}$ intravenous days $1,4,8,11$ \\
(Vel/Dex) & Dexamethasone $40 \mathrm{mg}$ oral days $1-4$ \\
& Repeated every 3 weeks $\times 4$ cycles as pre-transplant induction therapy \\
& \\
Melphalan-Prednisone- & Melphalan $0.25 \mathrm{mg} / \mathrm{kg}$ oral days $1-4$ \\
Thalidomide & Prednisone $2 \mathrm{mg} / \mathrm{kg}$ oral days $1-4$ \\
(MPT) & Thalidomide $100-200 \mathrm{mg}$ oral days $1-28$ \\
& Repeated every 6 weeks $\times 12$ cycles \\
Melphalan-Prednisone & Melphalan $9 \mathrm{mg} / \mathrm{m}^{2}$ oral days $1-4$ \\
-Bortezomib & Prednisone $60 \mathrm{mg} / \mathrm{m}^{2}$ oral days 1 to 4 \\
(MPV) & Bortezomib $1.3 \mathrm{mg} / \mathrm{m}^{2}$ intravenous days $1,4,8,11,22,25,29,32$ \\
& Repeated every 42 days $\times 4$ cycles followed by maintenance therapy as given below:
\end{tabular}

Melphalan $9 \mathrm{mg} / \mathrm{m}^{2}$ oral days $1-4$

Prednisone $60 \mathrm{mg} / \mathrm{m}^{2}$ oral days 1 to 4

Bortezomib $1.3 \mathrm{mg} / \mathrm{m}^{2}$ intravenous days $1,8,15,22$

Repeated every 35 days $\times 5$ cycles

Melphalan-Prednisone -Lenalidomide (MPR) 39

Bortezomib-ThalidomideDexamethasone (VTD)
Melphalan $0.18 \mathrm{mg} / \mathrm{kg}$ oral days $1-4$

Prednisone $2 \mathrm{mg} / \mathrm{kg}$ oral days $1-4$

Lenalidomide $10 \mathrm{mg}$ oral days $1-21$

Repeated every 4-6 weeks $\times 9$ cycles

Bortezomib $1.3 \mathrm{mg} / \mathrm{m}^{2}$ intravenous days $1,4,8,11$

Thalidomide $100-200 \mathrm{mg}$ oral days $1-21$

Dexamethasone $20 \mathrm{mg} / \mathrm{m}^{2}$ oral days $1-4$

Repeated every 4 weeks $\times 4$ cycles as pre-transplant induction therapy

*Starting and subsequent doses need to be adjusted for performance status, renal function, blood counts, and other toxicities Recommended dose of dexamethasone has been reduced from the published series to no more than 4 doses a month based on recent results of a trial comparing lenalidomide plus high dose dexamethasone versus lenalidomide plus low dose dexamethasone 
Table 2. New induction regimens tested in myeloma patients $<65$ years of age

\begin{tabular}{|c|c|c|c|c|c|c|c|c|c|c|c|}
\hline & Therapy & $\begin{array}{l}\text { No. of } \\
\text { patients }\end{array}$ & $\begin{array}{l}\text { Median age } \\
\text { (range) }\end{array}$ & $\underset{(\%)}{\geq}$ & $\begin{array}{l}\text { CR } \\
(\%)\end{array}$ & $\begin{array}{l}\text { Progression-free } \\
\text { Survival }\end{array}$ & $\begin{array}{l}\text { Overall } \\
\text { Survival }\end{array}$ & $\begin{array}{c}\text { Peripheral- } \\
\text { Neuropathy } \\
\text { grade 3-4 (\%) }\end{array}$ & $\begin{array}{c}\text { DVT } \\
\text { Embolism } \\
\text { grade 3-4 (\%) }\end{array}$ & $\begin{array}{c}\text { Infection } \\
\text { grade 3-4 (\%) }\end{array}$ & Reference \\
\hline \multirow[t]{5}{*}{ Diagnosis } & TD & 100 & $54(49-59)$ & 76 & 10 & ND & ND & 4 & 15 & 4 & 6 \\
\hline & TD & 103 & $65(38-83)$ & 63 & 4 & $50 \%$ at 22 months & $72 \%$ at 2 years & 7 & 17 & 7 & 12 \\
\hline & RD & 34 & $64(32-78)$ & 91 & 18 & $74 \%$ at 2 years & $91 \%$ at 2 years & ND & 3 & 6 & 17,18 \\
\hline & VD & 81 & 55 (ND) & 82 & 9 & ND & ND & 4 & 2 & 14 & 24 \\
\hline & ASCT-T & 323 & ND & ND & 62 & $56 \%$ at 5 years & $65 \%$ at 5 years & $27^{*}$ & $30^{*}$ & ND & 4 \\
\hline
\end{tabular}

ASCT-T: autologous transplant+thalidomide; CR: complete response; DVT: deep-vein thrombosis; ND: not deteminate; PR: partial response; RD: lenalidomide+ dexamethasone; TD: thalidomide+dexamethasone; VD: bortezomib+dexamethasone; *grade ? 2; "all grades; 'event-free survival

\begin{tabular}{|c|c|c|c|c|c|c|c|c|c|c|c|c|c|}
\hline & Therapy & $\begin{array}{l}\text { No. of } \\
\text { patients }\end{array}$ & $\begin{array}{l}\text { Median age } \\
\text { (range) }\end{array}$ & $\underset{(\%)}{\geq}$ & $\begin{array}{l}\mathrm{CR} \\
(\%)\end{array}$ & $\begin{array}{l}\text { Progression-free } \\
\text { Survival }\end{array}$ & $\begin{array}{l}\text { Overall } \\
\text { Survival }\end{array}$ & $\begin{array}{c}\text { Peripheral- } \\
\text { Neuropathy } \\
\text { grade 3-4 } \\
(\%)\end{array}$ & $\begin{array}{c}\text { DVT } \\
\text { Embolism } \\
\text { grade 3-4 } \\
(\%)\end{array}$ & $\begin{array}{c}\text { Neutro- } \\
\text { penia } \\
\text { grade 3-4 } \\
(\%)\end{array}$ & $\begin{array}{c}\text { Thrombo- } \\
\text { citopenia } \\
\text { grade 3-4 } \\
(\%)\end{array}$ & $\begin{array}{l}\text { Infection } \\
\text { grade 3-4 } \\
(\%)\end{array}$ & Reference \\
\hline \multirow[t]{4}{*}{ Diagnosis } & MPT & 124 & ND (65-75) & 81 & 16 & $50 \%$ at 28 months & $78 \%$ at 2 years & 6 & 12 & 48 & 14 & 13 & 32 \\
\hline & MPT & 129 & $72(60-85)$ & 76 & 16 & $54 \%$ at 2 years $^{\circ}$ & $80 \%$ at 3 years & 8 & 12 & 16 & 3 & 10 & 33 \\
\hline & MPR & 54 & $71(57-77)$ & 85 & 17 & $91 \%$ at 2 years ${ }^{\circ}$ & $92 \%$ at 2 years & 0 & 5 & 52 & 24 & 9 & 37 \\
\hline & VMP & 60 & $75(65-85)$ & 89 & 32 & $91 \%$ at 16 months & $90 \%$ at 16 months & 17 & ND & 43 & 51 & 16 & 35 \\
\hline
\end{tabular}

CR: complete response; DVT: deep-vein thrombosis; PR: partial response; MPR: melphalan+prednisone+lenalidomide; MPT: melphalan+prednisone+thalidomide; ND: not determine; event-free survival

dexamethasone is no longer recommended as initial therapy.

The main choices for initial therapy are Thal/Dex, bortezomib-based regimens, and lenalidomide-dexamethasone (Rev/Dex) (Tables 2 and 3). These new combinations act very rapidly and are associated with high response rates; Thal/Dex and Rev/Dex have the added advantage of being orally administered. The risk of deep vein thrombosis (DVT) increases with Thal/Dex and Rev/Dex and routine thromboprophylaxis is recommended.

\section{Thalidomide-Dexamethasone (Thal/Dex)}

The first clinical trial with thalidomide demonstrated a response rate of $25 \%$ in heavily pre-treated patients with relapsed refractory disease. ${ }^{9}$ Response rates in relapsed myeloma patients increased to $50 \%$ with the addition of corticosteroids; and to over $65 \%$ with a three-drug combination of thalidomide, corticosteroids and alkylating agents.

The use of Thal/Dex in newly diagnosed myeloma was initially based on three phase II clinical trials. ${ }^{10-12}$ The Eastern Cooperative Oncology Group (ECOG) recently compared Thal/Dex to dexamethasone in 207 patients. ${ }^{8}$ The best response within four cycles of therapy was significantly higher with Thal/Dex compared to dexamethasone alone $(63 \%$ versus $41 \%, \mathrm{P}=0.0017)$. Stem cell harvest was successful in $90 \%$ of patients in each arm. DVT was more frequent with Thal/Dex (17\% versus 3\%). Overall, grade 3 or higher nonhematologic toxicities were seen in $67 \%$ of patients treated with Thal/Dex and $43 \%$ in those treated with dexamethasone alone $(\mathrm{P}<0.001)$. Early mortality (first 4 months) was $7 \%$ with
Thal/Dex and 11\% with dexamethasone alone. Based on this trial, the United States Food and Drug Administration (FDA) granted accelerated approval for Thal/Dex for the treatment of newly diagnosed myeloma.

Preliminary results are available from a second randomized, double-blind, placebo-controlled study comparing Thal/Dex versus dexamethasone alone as primary therapy in 470 newly diagnosed MM patients. ${ }^{13}$ Among 470 pts enrolled, time to progression (TTP) was significantly superior with Thal/Dex, $\mathrm{P}<0.001$. As in the ECOG trial, DVT and other grade 3-4 events were more frequent with Thal/Dex.

Patients receiving thalidomide in combination with highdose steroids or chemotherapy need routine thromboprophylaxis with coumadin (target INR 2-3) or low-molecular weight heparin (equivalent of enoxaparin $40 \mathrm{mg}$ once daily). Aspirin can be used instead in patients receiving only low doses of dexamethasone ( $40 \mathrm{mg}, 4$ days a month or lower) or prednisone in combination with thalidomide, provided no concomitant erythropoietic agents are used.

\section{Lenalidomide-dexamethasone (Rev/Dex)}

Two large phase III trials have recently shown significantly superior response rate $(61 \%$ vs $22 \%, \mathrm{P}<0.001)$ and TTP (11.2 vs 4.7, $\mathrm{P}<0.001$ ) with lenalidomide plus dexamethasone (Rev/Dex) compared to placebo plus dexamethasone in relapsed myeloma. ${ }^{14-16}$ Based on these studies, Rev/Dex is currently approved by the FDA and EMEA for the treatment of myeloma in patients who have received one prior therapy.

A phase II trial conducted at the Mayo Clinic demonstrated remarkably high activity with the Rev/Dex 
regimen in newly diagnosed myeloma. Ninety-one percent of 34 patients achieved an objective response, including $6 \%$ of patients achieving complete response (CR), and $32 \%$ meeting criteria for very good partial response (VGPR). ${ }^{17}$ With longer follow-up, $56 \%$ of patients achieved at least a VGPR. ${ }^{18}$ Approximately $50 \%$ of patients experienced grade 3 or higher non-hematologic toxicity.

ECOG tested Rev/Dex as administered in the Mayo Phase II trial (and in the regulatory relapsed refractory myeloma studies) versus Rev/low-dose Dex (40 mg dexamethasone once weekly). ${ }^{19}$ Results so far show that toxicity rates are significantly higher with Rev/high-dose Dex compared to Rev/low-dose Dex. Early (first 4 month) mortality rates were low in both arms, $5 \%$ and $0.5 \%$ respectively. The early mortality rate in the Rev/low-dose dexamethasone arm is probably the lowest reported in any large phase III newly diagnosed trial in which enrollment was not restricted by age or eligibility for stem cell transplantation, making this one of the safest pre-transplant induction regimens for myeloma. This ECOG study was recently closed by the data monitoring committee because of significantly superior overall survival in patients receiving Rev/low-dose dexamethasone compared to Rev/high-dose dexamethasone. Based on these results, Rev/low-dose Dex is currently the regimen of choice at Mayo Clinic outside the setting of a clinical trial. As a result, doses of dexamethasone in excess of $40 \mathrm{mg}$ for 4 days each month are not recommended in patients with newly diagnosed myeloma, either as a single agent or in combination with other agents.

The incidence of DVT is low with single-agent lenalidomide or lenalidomide plus low-dose dexamethasone and increased significantly when the agent is combined with high-dose dexamethasone. Recommendations for thromboprophylaxis are similar to those discussed above with Thal/ Dex; aspirin alone is probably sufficient for patients receiving lenalidomide plus low-dose dexamethasone.

\section{Bortezomib-based regimens}

Bortezomib is a potent, reversible, and selective inhibitor of the proteasome targeting intracellular survival signaling pathways. Treatment with single agent bortezomib in relapsed/refractory patients showed an overall response rate of approximately $30 \%$ with an average response duration of 12 months..$^{20}$ Progression free survival (PFS) is superior with bortezomib compared to dexamethasone alone in patients with relapsed, refractory MM. ${ }^{21}$ Bortezomib is currently approved by the FDA and EMEA for the treatment of MM patients who have failed one prior therapy.

In newly diagnosed myeloma, bortezomib has shown response rates of approximately $40 \%$ as a single-agent, ${ }^{22}$ and significantly higher response rates $(70 \%-90 \%)$ in combination with dexamethasone (Vel/Dex), ${ }^{23,24}$ or thalidomide and dexamethasone (VTD), or other chemotherapy combinations. No adverse effect on stem cell mobilization has been noted.
The most common grade 2 or higher adverse events in one study were sensory neuropathy (31\%), constipation (28\%), myalgia $(28 \%)$ and fatigue $(25 \%) .{ }^{23}$ Harousseau and colleagues recently reported preliminary results of a randomized trial comparing VAD versus Vel/Dex as pretransplant induction therapy. ${ }^{25}$ With over 400 patients enrolled, preliminary results show superior response rates and long-term outcome with Vel/Dex compared to VAD. No increased risk of DVT was observed with bortezomib- based regimen $(<5 \%)$.

The main drawback of bortezomib-based therapy is the need for intravenous therapy. However, bortezomib-based regimens may be of value in patients with renal failure, and in patients with high-risk myeloma.

\section{Transplantation}

In newly diagnosed myeloma patients younger than 65 years, high-dose melphalan followed by autologous stem cell transplantation is considered the standard of care. An increasing number of patients are opting for delayed transplantation. There is also new interest in allografting. In a recent trial, newly diagnosed multiple myeloma patients received an ASCT followed by an allograft from an HLAidentical sibling or a tandem ASCT. Patients with an HLAidentical sibling were first treated with an ASCT and then received nonmyeloablative total-body irradiation and stem cells from the sibling. Patients without an HLA-identical sibling received two consecutive myeloablative doses of melphalan, each of which was followed by autologous stemcell rescue. The median OS and EFS were longer in patients with HLA-identical siblings than in those without HLAidentical siblings ( 80 months vs. 54 months, $\mathrm{P}=0.01$; and 35 months vs. 29 months, $\mathrm{P}=0.02$, respectively). These data suggest that survival in recipients of a hematopoietic stemcell autograft followed by a stem-cell allograft from an HLAidentical sibling may be superior to that in recipients of tandem stem-cell autografts. ${ }^{26}$ Further studies are needed to confirm these findings in the context of improved initial therapeutic approaches discussed below.

\section{Maintenance therapy}

The role of maintenance therapy remains controversial in myeloma. After conventional or high-dose therapy, maintenance with interferon-alpha provided marginal benefits. In patients who responded to conventional chemotherapy, maintenance therapy with $50 \mathrm{mg}$ alternateday prednisone significantly improved PFS and OS in comparison with $10 \mathrm{mg}$ alternate-day prednisone. ${ }^{27}$

In a large French randomized study, patients younger than 65 years were randomly assigned to receive no maintenance, pamidronate, or pamidronate plus thalidomide. ${ }^{28}$ The 3-year post-randomization probability of EFS and the 4year OS were significantly prolonged in patients who received thalidomide $(\mathrm{P}<0.009$ and $\mathrm{P}<0.04$, respectively). Grade 3-4 
neuropathy $(7 \%)$, fatigue $(6 \%)$ and constipation $(1 \%)$ were more prominent in the thalidomide group, while the incidence of thromboembolic events was not significantly different in the 3 arms. A recently randomized trial compared thalidomideprednisone versus prednisone alone as maintenance therapy after ASCT: the 1-year progression-free survival was $91 \%$ vs $69 \%$, and the 2 -year overall survival was $90 \%$ vs $81 \%$ respectively. Neurological side effects were more common with thalidomide, but no differences were observed in the incidence of thromboembolic events. ${ }^{29}$ Additional studies are needed to determine the role of routine maintenance in myeloma, especially the use of lenalidomide which has a better safety profile than thalidomide for long-term maintenance.

\section{Treatment of myeloma in patients not eligible for ASCT}

Patients who are not transplant candidates are treated with standard alkylating agent therapy. Since the 1960s melphalan-based chemotherapy had played a central role in the treatment of multiple myeloma. Oral, intermittent association of melphalan and prednisone (MP) has been the most widely used schedule for elderly patients. Over the years, despite better response rates, no survival benefit has been reported with any of the more aggressive combination chemotherapy regimens compared to MP.

In a recent randomized trial the MP regimen was compared with melphalan plus dexamethasone, high-dose dexamethasone, or high-dose dexamethasone plus interferonalpha. ${ }^{30}$ Response rate was significant higher among patients receiving melphalan-dexamethasone. Median PFS was 21 and 23 months after MP or melphalan plus dexamethasone, but only 12 and 15 months after high-dose dexamethasone or high-dose dexamethasone plus interferon-alpha, respectively. However, no difference in overall survival was reported among the 4 different groups. Melphalan should be incorporated in the induction regimen for elderly patients who are not candidates for autologous transplant.

Despite its proved efficacy, melphalan $200 \mathrm{mg} / \mathrm{m}^{2}$ followed by autologous transplant can be accepted only for patients up to the age of 65 , since in elderly patients the treatment-related mortality is higher. Conditioning regimens with intermediate dose melphalan have been performed, in order to extend the transplant benefit to patients aged over 65 years. Intermediate-dose melphalan $\left(100-140 \mathrm{mg} / \mathrm{m}^{2}\right)$ appears more suitable in this group patients. In one study, patients were aged $65-70$ years and melphalan $100 \mathrm{mg} / \mathrm{m}^{2}$ was superior to MP. ${ }^{31}$ In another study, patients were aged 65-75 years and melphalan $100 \mathrm{mg} / \mathrm{m}^{2}$ was superior to MP in terms of response rate, but not in terms of PFS and OS. ${ }^{32}$ In the first study, $22 \%$ of patients did not complete the assigned treatment; in the second trial, $37 \%$ of patients did not complete it. According to these data, the age of 70 years may be suggested as the age limit for intermediate-dose melphalan.

Recently 3 new induction regimen suitable for elderly patients, have emerged: melphalan, prednisone, thalidomide (MPT); melphalan, prednisone, lenalidomide (MPR), and melphalan, prednisone, bortezomib (Table 2).

Melphalan, prednisone, thalidomide (MPT)

Two randomized studies show that MPT improves response rate and EFS compared to MP; $; 2,33$ an overall survival advantage has been reported in one of the two trials. ${ }^{32}$

In the Italian randomized trial, oral MPT was compared with MP in patients aged 60-85 years. ${ }^{33}$ The partial response (PR) rates were $76 \%$ in MPT patients and $47.6 \%$ in MP subjects, near-CR or CR rates were $27.9 \%$ and $7.2 \%$, respectively. The 2-year EFS was $54 \%$ for MPT and $27 \%$ for MP $(p=0.0006)$. The 3 -year OS was $80 \%$ and $64 \%$, respectively $(\mathrm{p}=0.19)$. MPT was associated with a higher risk of grade 3-4 neurological adverse events (10\% vs $1 \%)$, infections $(10 \%$ vs $2 \%, \mathrm{p}=0.001)$, cardiac toxicity ( $7 \%$ vs $4 \%$ ) and thromboembolism ( $12 \%$ vs $2 \%$ ) compared to MP regimen. Introduction of enoxaparin prophylaxis significantly reduced the rate of thromboembolism from $20 \%$ to $3 \%$ ( $\mathrm{p}=0.005$ ).

In the French phase III trial, MPT was compared with MP and with intermediate-dose melphalan $\left(100 \mathrm{mg} / \mathrm{m}^{2}\right)$ followed by autologous stem cell transplantation. A higher PR rate was seen in the MPT and in the melphalan $100 \mathrm{mg} / \mathrm{m}^{2}$ arms, compared to MP ( $81 \%$ vs $73 \%$ vs $40 \%$, respectively). ${ }^{32}$ Similarly, the CR rates were significantly higher with MPT and intermediate-dose melphalan compared to MP. PFS was superior in the MPT patients compared with both MP $(p<0.001)$ and autologous transplantation $(p=0.001)$. Furthermore, OS was significantly improved in the MPT group in comparison with both MP $(\mathrm{p}=0.001)$ and autologous transplantation $(\mathrm{p}=0.004)$. MPT was associated with a higher risk of grade 3-4 neutropenia, infections, thrombocytopenia, thromboembolic complications, peripheral neuropathy, constipation, and cardiac events. These data along with the Italian study strongly support the use of MPT as standard of care in elderly patients with newly diagnosed myeloma.

Antithrombotic prophylaxis is recommended when using MPT. At present there is no evidence of the best prophylaxis: low-molecular-weight heparin, therapeutic doses of warfarin, or daily aspirin are the preferred options. ${ }^{34}$

\section{Melphalan, prednisone, bortezomib (MPV)}

The Spanish cooperative group conducted a large phase I/II trial of bortezomib, melphalan, and prednisone (MPV). ${ }^{35}$ Overall response rate was $89 \%$, including $32 \%$ immunofixation-negative $\mathrm{CR}$ with half of them achieved immunophenotypic remission (no detectable plasma cells at 10-4 to 10-5 sensitivity). PFS at 16 months for patients treated with VMP combination was significantly prolonged in comparison with historical controls treated with MP only (91\% versus 66\%); similarly OS at 16 months was improved 
(90\% versus $62 \%$ ). No impact of chromosome 13 deletion or IgH translocations was observed on both response rate and survivals. The most frequent grade 3-4 adverse events were thrombocytopenia, neutropenia, peripheral neuropathy, infections and diarrhea. The treatment appeared more toxic in patients older then 75 years and during early cycles. Bortezomib may induce transient thrombocytopenia and peripheral neuropathy. Pre-existing neuropathy or previous neurotoxic therapy increases the risk of peripheral neuropathy, which can be reduced or resolved by timely dose-adjustment of the drug. Bortezomib may enhance the incidence of infections, in particular herpes zoster reactivation, and prophylactic antiviral medications are highly recommended. Preliminary data from a large international randomized study comparing VMP with standard MP treatment, appeared to confirm the results from phase I/II study. ${ }^{36}$

\section{Melphalan, prednisone, lenalidomide (MPR)}

In a phase I/II trial safety and efficacy of melphalan plus prednisone in combination with lenalidomide (MPR) in newly diagnosed elderly myeloma patients were studied. ${ }^{37}$ At the maximum tolerated dose (lenalidomide $10 \mathrm{mg}$ plus melphalan $0.18 \mathrm{mg} / \mathrm{kg}$ ), $85 \%$ of patients achieved at least a PR and 23.8\% immunofixation negative CR. The 1-year EFS and OS were $92 \%$ and $100 \%$. The corresponding 1 -year EFS and OS were $78 \%$ and $87.4 \%$ in historical MPT treated patients. Preliminary results showed that the EFS of patients with deletion of chromosome 13 or chromosomal translocation $(4 ; 14)$ was not significantly different from those who did not have show such abnormalities. By contrast, patients with high-levels of serum B2-microglobulin experienced a shorter EFS in comparison with those who showed low-levels of B2microglobulin. Grade 3-4 adverse events were mainly related to hematological toxicities (neutropenia 66\%). Severe nonhematological side effects were less frequent and were febrile neutropenia $(8 \%)$, cutaneous rash $(10 \%)$ and thromboembolism (6\%). Rate of thrombotic complication was low with daily low dose aspirin prophylaxis. The MPR schema is now under evaluation in a larger international randomized phase III trial in comparison with MP, the results of this ongoing trial will probably define its role in the therapeutic algorithm for elderly myeloma patients.

\section{Treatment of high-risk myeloma}

Patients with high-risk myeloma have a poor prognosis, with median overall survival of approximately two years even with tandem ASCT. Novel agents could have a role in therapeutic strategies for this patients, for example Bortezomib containing regimens can be considered early in the disease course as primary therapy, with stem cell transplantation reserved for relapse. In different separate studies, bortezomib appears to overcome the adverse effect of deletion $13 .{ }^{38,39}$ Allogeneic approaches may be an option in selected patients.
However, the recent IFM 99 trial in patients with deletion 13 and high $\beta 2$-microglobulin levels has not shown significant benefit with this strategy compared to tandem ASCT. ${ }^{40}$

In case patients are treated similar to standard-risk patients, routine maintenance therapy should be considered (eg., thalidomide plus prednisone) given the high risk of relapse. Clearly, clinical trials and new agents specifically designed for high-risk myeloma are needed.

\section{Conclusion}

High-dose melphalan followed by autologous stem cell transplantation in the younger patients and oral melphalanprednisone-thalidomide in the elderly are the standard of care for newly diagnosed multiple myeloma. Survival after transplant appears to be related to the achievement of CR or VGPR. Improved response rate after induction treatment, prior to transplant, could translate into a better results after high-dose therapy and into a prolonged survival. In younger patients, combinations incorporating thalidomide or lenalidomide or bortezomib significantly increases the pretransplant CR rate before high-dose melphalan and autologous transplantation. These combinations may further improve the $\mathrm{CR}$ rate achieved after transplant.

Cytogenetic abnormalities, such as deletion of chromosome 13 or chromosomal translocation $(4 ; 14)$ are considered negative prognostic factors. In the MPV patients, as well as in a smaller cohort of MPR patients, the event-free survival of patients with deletion of chromosome 13 or chromosomal translocation $(4 ; 14)$ was not significantly different from those who did not show such abnormalities. If these data will be confirmed, it seems likely that a cytogenetically adapted strategy will represent the most rational, molecularly targeted approach to myeloma therapy. Prospective randomized studies incorporating new agents and stratifying patients based on cytogenetic abnormalities, are needed.

\section{Resumo}

O avanço do conhecimento da patogênese do mieloma múltiplo e do mecanismo de resistência a drogas propiciou o desenvolvimento de novas terapias alvo que vençam a resistência e apresentem efeitos sinérgicos e aditivos aos velhos agentes quimioterápicos. A talidomida, e o seu derivado imonumodulador, lenalidomida, e o inibidor da proteasoma bortezomib, em combinação com o melfalano no idoso e intravenoso no jovem, estão mudando os paradigmas tradicionais de tratamento do mieloma múltiplo. Altas doses de melfalano seguidas do transplante de células-tronco autólogo no paciente jovem e o tratamento oral de melfalano-predimisonatalidomida no idoso são agora tratamentos padrões para os portadores de mieloma múltiplo recém-diagnosticados. Nos pacientes jovens, as incorporações de combinações de talidomida ou lenamidomida ou bortezomib aumentam significativamente as taxas de 
respostas pré-transplante autólogo. Estas medidas melhoram as taxas de respostas e de sobrevida observadas após o transplante. Estudos prospectivos randomizados incorporam novos agentes para o tratamento de pacientes estratificados em anormalidades citogenéticas e são necessários para os pacientes com auto risco. Rev. bras. hematol. hemoter. 2008;30(Supl. 2):10-17.

Palavras-chave: Mieloma; lenamidomida; talidomida; bortezomibe; terapia.

\section{References}

1. Kyle RA, Rajkumar SV. Multiple Myeloma. N Engl J Med. 2004; 351(18):1860-73.

2. Rajkumar SV, Kyle RA. Multiple Myeloma: Diagnosis and Treatment. Mayo Clin Proc. 2005;80(10):1371-82.

3. Ries LAG, Eisner MP, Kosary CL, Linet M, Tamra T, Young JL, et al. SEER cancer statistics review, 1975-2000. National Cancer Institute. Available at: http//seer.cancer.gov//csr/1975_2001. Accessed on september 7, 2004.

4. Cavo M, Zamagni E, Tosi P, Tacchetti P, Cellini C, Cangini D, et al. Superiority of thalidomide and dexamethasone over vincristinedoxorubicindexamethasone (VAD) as primary therapy in preparation for autologous transplantation for multiple myeloma. Blood. 2005;106(1):35-9.

5. Fermand J-P, Jaccard A, Macro M, et al. A randomized comparison of dexamethasone + thalidomide (Dex/Thal) vs Dex + Placebo $(\mathrm{Dex} / \mathrm{P})$ in patients (pts) with relapsing multiple myeloma (MM). Blood. 2006;108:3563.

6. Macro M, Divine M, Uzunhan Y, Jaccard A, Bouscary D, Leblond V et al. Dexamethasone+Thalidomide (Dex/Thal) compared to VAD as a pre-transplant treatment in newly diagnosed, ultiple myeloma (MM): A Randomized Trial. Blood. 2006;108:57.

7. Barlogie B, Tricot G, Anaissie E, Shaughnessy J, Rasmussen E, Van Rhee $\mathrm{F}$ et al. Thalidomide and hematopoietic-cell transplantation for multiple myeloma. N Eng1 J Med 2006;354(10):1021-30.

8. Rajkumar SV, Blood E, Vesole DH, Fonseca R, Greipp PR. Phase III clinical trial of thalidomide plus dexamethasone compared with dexamethasone alone in newly diagnosed multiple myeloma: A clinical trial coordinated by the Eastern Cooperative Oncology Group. J Clin Oncol. 2006;24(3):431-6.

9. Singhal S, Mehta J, Desikan R, Ayers D, Roberson P, Eddlemon P, et al. Antitumor activity of thalidomide in refractory multiple myeloma. N Engl J Med. 1999;18;341(21):1565-71.

10. Rajkumar SV, Hayman S, Gertz MA, Dispenzieri A, Lacy MQ, Greipp PR et al. Combination therapy with thalidomide plus dexamethasone for newly diagnosed myeloma. J Clin Oncol. 2002;20(21):4319-23.

11. Weber DM, Gavino M, Delasalle K, Rankin K, Giralt S, Alexanian R. Thalidomide alone or with dexamethasone for multiple myeloma. Blood. 1999;94 (Suppl 1):604a (A 2686).

12. Cavo M, Zamagni E, Tosi P, Cellini C, Cangini D, Tacchetti P et al. First-line therapy with thalidomide and dexamethasone in preparation for autologous stem cell transplantation for multiple myeloma. Haematologica. 2004;89(7):826-31.

13. Rajkumar SV, Hussein M, Catalano J, et al. Multicenter, randomized, double-blind, placebo-controlled study of thalidomide plus dexamethasone compared with dexamethasone as initial therapy for newly diagnosed multiple myeloma. J Clin Oncol. 2008 1;26(13):2171-7.

14. Dimopoulos M, Spencer A, Attal M, Prince HM, Harousseau JL, Dmoszynska A, et al. Lenalidomide plus dexamethasone for relapsed or refractory multiple myeloma. N Engl J Med 2007; 357(21): 2123-32.

15. Weber D, Chen C, Niesvizky R, Wang M, Belch A, Stadtmauer EA, et al. Lenalidomide plus dexamethasone for relapsed multiple myeloma in North America. N Engl J Med 2007;357 (21):2133-42.

16. Weber D, Knight R, Chen C, et al. Prolonged overall survival with lenalidomide plus dexamethasone compared with dexamethasone alone in patients with relapsed or refractory multiple myeloma. Blood. 2007;110:128a.

17. Rajkumar SV, Hayman SR, Lacy MQ, Dispenzieri A, Geyer SM, Kabat B, et al. Combination therapy with lenalidomide plus dexamethasone (Rev/Dex) for newly diagnosed myeloma. Blood. 2005;106(13):4050-3.

18. Lacy M, Gertz MA, Dispenzieri A, Hayman SR, Geyer S, Kabat B et al. Long-term results of response to therapy, time to progression, and survival with lenalidomide plus dexamethasone in newly diagnosed myeloma. Mayo Clin Proc 2007;82(10):1179-84.

19. Rajkumar SV, Jacobus S, Callander N, Fonseca R, Vesole D, Greipp P. A randomized phase III trial of lenalidomide plus high-dose dexamethasone versus lenalidomide plus low-dose dexamethasone in newly diagnosed multiple myeloma (E4A03): A Trial Coordinated by the Eastern Cooperative Oncology Group. Blood. 2006; 108:799.

20. Richardson PG, Barlogie B, Berenson J, Singhal S, Jagannath S, Irwin $\mathrm{D}$, et al. A phase 2 study of bortezomib in relapsed, refractory myeloma. N Engl J Med. 2003;348(26):2609-17.

21. Richardson PG, Sonneveld P, Schuster MW, Irwin D, Stadtmauer EA, Facon T, et al. Bortezomib or high-dose dexamethasone for relapsed multiple myeloma. N Engl J Med. 2005;352(24):2487-98.

22. Richardson PG, Chanan-Khan A, Schlossman RL, et al. Phase II trial of single agent bortezomib (Velcade $\left.{ }^{\circledR}\right)$ in patients with previously untreated multiple myeloma (MM). Blood. 2004; 104:100a (A336).

23. Jagannath S, Durie BG, Wolf J, Camacho E, Irwin D, Lutzky J, et al. Bortezomib therapy alone and in combination with dexamethasone for previously untreated symptomatic multiple myeloma. Br J Haematol. 2005;129(6):776-83.

24. Harousseau J, Attal M, Leleu X, Troncy J, Pegourie B, Stoppa AM, et al. Bortezomib plus dexamethasone as induction treatment prior to autologous stem cell transplantation in patients with newly diagnosed multiple myeloma: results of an IFM phase II study. Haematologica. 2006;91(11):1498-505.

25. Harousseau J-L, Marit G, Caillot D, et al. Velcade/dexamethasone (Vel/Dex) versus VAD as induction treatment prior to autologous stem cell transplantation (ASCT) in newly diagnosed multiple myeloma (MM): an interim analysis of the IFM 2005-01 Randomized Multicenter Phase III Trial. Blood. 2006;108:56.

26. Bruno B, Rotta M, Patriarca F, Mordini N, Allione B, CarnevaleSchianca F, et al. A comparison of allografting with autografting for newly diagnosed myeloma. N Engl J Med. 2007;356(11):1110-20

27. Berenson JR, Crowley J, Grogan TM, Zangmeister J, Briggs AD, Mills GM et al. Maintenance therapy with alternate-day prednisone improves survival in multiple myeloma patients. Blood. 2002; 99(9):3163-8.

28. Attal M, Harousseau JL, Leyvraz S, Doyen C, Huylin C, Benboubker L et al. Maintenance therapy with thalidomide improves survival in patients with multiple myeloma. Blood. 2006;108(10):3289-94.

29. Spencer A, Prince M, Roberts AW, Bradstock KF, Prosse IW. First analysis of the Australasian Leukaemia and Lymphoma Group (ALLG) Trial of Thalidomide and Alternate Day Prednisolone Following Autologous Stem Cell Transplantation (ASCT) for 
Patients with Multiple Myeloma (ALLG MM6). Blood. 2006; 108:58a.

30. Facon T, Mary JY, Pegourie B, Attal M, Renaud M, Sadoun A, et al. Dexamethasone-based regimens versus melphalan-prednisone for elderly multiple myeloma patients ineligible for high-dose therapy. Blood. 2006;107(4):1292-8.

31. Palumbo A, Bringhen S, Petrucci MT, Musto P, Rossini F, Callea V, et al. Intermediate-dose melphalan improves survival of myeloma patients aged 50 to 70 : results of a randomized controlled trial Blood. 2004;104(10):3052-7.

32. Facon T, Mary J, Hulin C, Benboubker L, Attal M, Pegourie B, et al. Melphalan and prednisone plus thalidomide versus melphalan and prednisone alone or reduced-intensity autologous stem cell transplantation in elderly patients with multiple myeloma (IFM 99-06): a randomised trial. Lancet. 2007;370(9594):1209-18.

33. Palumbo A, Bringhen S, Caravita T, Merla, Capparella V, Callea V, et al. Oral melphalan and prednisone chemotherapy plus thalidomide compared with melphalan and prednisone alone in elderly patients with multiple myeloma: randomised controlled trial. Lancet. 367(9513):825-31.

34. Bennet CL, Angelotta C, Yarnold PR, Evens AM, Zonder A, Raisch DW, et al. Thalidomide and lenalidomide-associated thromboembolism among patients with cancer. JAMA 2006; 296 (21):2559-60.

35. Mateos MV, Hernandez JM, Hernandez MT, Guiterrez N-C, Palomera $\mathrm{L}$, Fuertes $\mathrm{M}$ et al. Bortezomib plus melphalan and prednisone in elderly untreated patients with multiple myeloma: results of a multicenter phase 1/2 study. Blood. 2006;108(7):2165-72.

36. San Miguel JF, Schlag R, Khuageva N, et al. MMY3002: A phase III study comparing bortezomib-melphalan-prednisone (VMP) with melphalan-prednisone (MP)in newly diagnosed multiple myeloma. Blood. 2007;110:76a
37. Palumbo A, Falco P, Falcone A, Corradini P, Di Raimondo F, Giuliani $\mathrm{N}$ et al. Oral revlimid plus melphalan and prednisone (RMP) for newly diagnosed multiple myeloma: a phase I-II study. J Clin Oncol. 2007;25:4459-65.

38. Jagannath S, Richardson PG, Sonneveld P, Schuster MW, Irwin D, Stadtmauer EA, et al. Bortezomib appears to overcome the poor prognosis conferred by chromosome 13 deletion in phase 2 and 3 trials. Leukemia. 2007;21(1):151-7. Epub 2006 Nov 9.

39. Sagaster V, Ludwig H, Kaufmann H, Odelga V, Zojer N, Ackerman $\mathrm{J}$ et al. Bortezomib in relapsed multiple myeloma: response rates and duration of response are independent of a chromosome 13qdeletion. Leukemia. 2007;21(1):164-8. Epub 2006 Nov 9.

40. Garban F, Attal M, Michallet M, Hulin C, Bourhis JH, Yakoub-Agha $\mathrm{I}$, et al. Prospective comparison of autologous stem cell transplantation followed by dose-reduced allograft (IFM99-03 trial) with tandem autologous stem cell transplantation (IFM99-04 trial) in high-risk de novo multiple myeloma. Blood. 2006;107:3474-80.

$A P$ has received scientific advisory-board and lecture fees from Pharmion, Celgene and Janssen-Cilag.

O tema apresentado constou do programa do Encontro AIBE. Avaliadores: Professores Ângelo Maiolino, Cármino Antonio de Souza e Marcio Nucci.

Publicado após concordância do editor.

Conflito de interesse: sem conflito de interesse

Recebido: 14/05/2008

Aceito: 16/05/2008 